\title{
Review
}

\section{Christian human rights}

\author{
Samuel Moyn \\ Philadelphia, University of Pennsylvania Press, 2015, ix+248 pp., \\ ISBN: 978-0-8122-4818-0
}

Contemporary Political Theory (2018) 17, S228-S231. https://doi.org/10.1057/s41296017-0151-x; published online 19 September 2017

In May 1977, President Jimmy Carter spoke at the University of Notre Dame's commencement. He outlined a foreign policy focused on the defence and promotion of human rights around the world. It set out an important new agenda for the United States, one which stood in contrast to the singular focus on defeating communism that had characterized so much of post-war American foreign policy. Interestingly, though the speech was given at the premier Catholic university in the United States, President Carter's only mention of Christianity was to acknowledge three other honorary degree recipients on stage with him: two cardinals and a bishop from the developing world. If the first 'born-again' Christian president speaking about human rights at a Catholic university fails to make the connection, it would seem Christianity and human rights have little in common.

The failure to connect the human rights agenda to Christianity perhaps reflects the widespread assumption that human rights are very much a victory of secular Enlightenment thought. So Samuel Moyn's recent book, Christian Human Rights, provides a welcome corrective to this narrative. In a creative genealogical study, Moyn's effort entails 'looking not so much at Jesus (or even at the Reformation), but at novel mid-twentieth-century interpretations of what his teachings demand, to understand how the huge set of possibilities the Christian legacy bequeathed was winnowed down' (p. 6). Moyn analyses four such moments of interpretation: the 1937 Irish Constitution; the development of the personalist philosophy of French Catholic social theorists such as Jacques Maritain; the historiography of the German Protestant Gerhard Ritter and the role of various Catholic and Protestant movements in the construction of European human rights institutions. In all four of these instances, Moyn brings forth the centrality of human dignity and its emphasis on a particularly Christian understanding of the human person.

Moyn's account unsettles standard assumptions in a number of different ways. The Catholic Church in the 18th and 19th century stood adamantly opposed to rights, as they were seen to be a heritage of the French Revolution's secularism and to constitute an atomising ideology that undermined the family and the authority of

(C) 2017 Macmillan Publishers Ltd. 1470-8914 Contemporary Political Theory Vol. 17, S4, S228-S231 
the Church. So the shift from opposing rights to embracing human rights required serious intellectual interpretive work by figures such as Maritain, whose role in the formulation of the Universal Declaration of Human Rights has been explored by Mary Anne Glendon (2002) and John Nurser (2005). Moyn locates the role of Maritain in a wider Catholic European context and moves his analysis away from the Universal Declaration of Human Rights, which receives only a brief mention. In so doing, he demonstrates how Catholic conservatives become converts to human rights both before and after World War II. For instance, in the chapter on the Irish Constitution of 1937, he outlines how the Irish leader Éamon de Valera integrated the idea of human dignity into the preamble and the overall text, a move which allowed him to bring on board conservative Catholics yet protect the language of rights. Moyn further demonstrates the ways in which this constitutional language influenced Christian movements and parties in Europe, enabling them to draw on and utilize the concept of rights in their own political and ideological agendas.

His chapter on the Catholic context draws not only on Maritain but on other figures in France and throughout Europe. This chapter is perhaps the least interesting, only because it has been covered by others, such as Nurser (2005). The chapter on Gerhard Ritter, the German historian and Protestant activist, provides new insights into the ways in which human rights did not just arise from German efforts to understand the Holocaust, but how those efforts were linked to religious ideas. Ritter's history of human rights, written by a staunch German Lutheran, surprisingly highlighted the importance of the Catholic natural law tradition. At the same time, unlike Maritain, Ritter 'acknowledged more honestly ... that the old natural law metaphysics of the "human person" did not flow directly into the new human rights; instead, for Ritter, human rights were at best a proxy for the primacy of that person that Christianity had once protected without modern compromises' (p. 122). Ritter's historical account is flawed in places, but Moyn's analysis of his role in the Christian historiography of human rights links his ideas with currents within Christian realism that shaped Protestant thinking in Europe and the United States during the mid-20th century.

The final chapter on the role of Christianity in the creation of European human rights courts and institutions adds further insights. It concludes with reflections on the struggles which Europe faces in integrating its Muslim citizens into their various national contexts and how those struggles have become matters of concern in European courts. Moyn insightfully points to the difficulties in this process by examining some cases around the wearing of the headscarf, cases which reveal the limits of modern day human rights. Indeed, as Moyn notes: 'Most of all, if human rights should remain central to collective politics, they would have to come in a version that would finally transcend their Christian incarnation - for in a certain sense, the Muslim headscarf cases show contemporary human rights to be not too secular but not secular enough' (p. 167).

(C) 2017 Macmillan Publishers Ltd. 1470-8914 Contemporary Political Theory Vol. 17, S4, S228-S231 S229 
Overall, this is an excellent book, one that raises and answers important questions about the history of human rights. After reading it, this reviewer is left with two questions for the author. First, Moyn has warned historians of human rights not to 'distort the past to suit the present' (Moyn, 2014, p. 1). His book The Last Utopia (2010) is rightly celebrated for correcting some of the grand assumptions about the progressivism of the Enlightenment by demonstrating the importance of the 1970s for the realization of the current human rights system. Christian Human Rights undertakes a very different kind of genealogy, one that locates human rights within European political developments of the early 20th century. As a result of these different starting points, the two genealogies do not connect very well. Of course, a genealogy does not fit into a single narrative, so to ask that they work together is perhaps unfair. But the contrast between the two accounts is stark enough so that some reflection on their relation might have been useful in the concluding chapters.

The second question is more about Christianity than about human rights. We cannot all be masters of every literature, but in raising the questions that he does, Moyn enters into theological controversies which he might have explored at greater length. For instance, in his discussion of Ritter, he asserts that Christian realism 'was and remains dubious' (p. 104). On what grounds is it dubious? Reinhold Niebuhr famously articulated a theology of Christian realism that continues to resonate with many. That realism relies on the Christian idea of original sin, which assumes that while we strive to be good, our very nature prevents it. For Niebuhr and others, this means that efforts to seek power over others can only be countered by institutional forms and political practices that acknowledge these failings. The Christian realist's scepticism about power might well connect with constitutional ideas of separation of powers and even, if they are seen as protections against intrusive government forces, human rights. Christian realism, in other words, may not be as far from contemporary human rights as Moyn suggests.

These remain quibbles, though, as this book deserves to be read. Moyn has opened up an important avenue of research, one that would benefit not only contemporary debates about Muslims in Europe, but perhaps also LGBT rights. For if the personalism of Maritain and others provides an important foundational dimension of human rights, it is hard to see how such natural law assumptions will benefit those who wish to transcend settled norms of gender and sexuality. His book leaves us with an important question: If human rights are so tied to Christian assumptions, can they do the work which so many in the contemporary world wish them to do?

\section{References}

Glendon, M. A. (2002). A World Made New: Eleanor Roosevelt and the Universal Declaration of Human Rights. New York: Random House. 
Moyn, S. (2010). The Last Utopia: Human Rights in History. Cambridge MA: Harvard University Press. Moyn, S. (2014). Human Rights and the Uses of History. London: Verso.

Nurser, J. S. (2005). For All Peoples and All Nations: The Ecumenical Church and Human Rights. Washington DC: Georgetown University Press.

Anthony F. Lang Jr. University of St Andrews, St Andrews KY16 9AX, Scotland, UK al51@st-andrews.ac.uk 